Kalpa Publications in Civil Engineering
Volume 1, 2017, Pages 410-417
ICRISET2017. International Conference on Re-
search and Innovations in Science, Engineering
\&Technology. Selected papers in Civil Engineering $\quad$ Ka L po

\title{
Evolution of ENSO Related Rainfall Anomalies for Lower Tapi River, India
}

\author{
Paresha M. Baria ${ }^{1}$ and Dr. S. M. Yadav ${ }^{2}$ \\ ${ }^{1}$ Civil Engineering Department, Sardar Vallabhbhai National Institute of Technology, Surat, India \\ ${ }^{2}$ Civil Engineering Department, Sardar Vallabhbhai National Institute of Technology, Surat, India \\ pmbaria@gmail.com, shivnam27@gmail.com
}

\begin{abstract}
The present study is an attempt to detect anomalies in rainfall for lower Tapi basin due to ENSO events. Daily rainfall data have been used for the present analysis. The data have been collected from state water data centre from 1961 to 2001. With the availability of suitable data 1982, 1986, 1987, 1991, 1997, 2002 and 2009 are the El Nino years and 1988, 1998, 1999, 2007 and 2010 are the La Nina years analysed for the present study. The yearly extreme precipitation indices have been computed for frequency, intensity and duration for the base period 1981 to 2010. For the El Nino years 1997 and 2009 positive anomalies have been observed in the frequency based indices. In the years 1982, 1987, 1991, 1997, 2002 and 2009, positive anomalies have been observed for the intensity based indices. Positive anomalies results into better rainfall during El Nino events. Negative anomalies have been observed in the years 1998 and 1999 of the La Nina events for the frequency based indices and for the years 1988, 1998, 1999, 1007 and 2010 negative anomalies have been observed in the intensity based indices. The analysis of La Nina events results in a decrease in rainfall. The precipitation duration based indices have not indicated clear trend. The overall analysis showed that ENSO is not directly affecting the rainfall of the study region.
\end{abstract}

Keywords- ENSO; El Nino; La Nina; Extreme climate indices; Anomalies; Lower Tapi basin

\section{Introduction}

According to International research institute for climate and society, Gilbert Walker found out in the late 1800's, the presence of dry spell in India is associated with movements in El Nino Southern Oscillation (ENSO). Most significant dry seasons are appeared to happen amid El Niño occasions and better than expected precipitation is appearing to happen amid La Nina occasions in India. The climatic change is observed by the El Nino Southern Oscillation phenomenon. Many researchers have

C.D. Modhera, G.J. Joshi, D. Soni, I.N. Patel, A.K. Verma, L.B. Zala, S.D. Dhiman, D.R. Bhatt, J.M. Rathod, B.C. Goradiya, M.S. Holia and D.K. Patel (eds.), ICRISET2017 (Kalpa Publications in Civil Engineering, vol. 1), pp. 410-417 
studied the association between ENSO anomalies and their impact on climate all through the globe (Andreoli et al., 2005; Arblaster et al., 2012; Donat et al. 2014, Bothale et al., 2015). El Nino event is a warm phase and La Nina event is a cool phase of ENSO. Bothale et al. (2014), study identified that rainfall shows positive anomaly for the period of La Nina events and negative anomaly observed all through the periods of El Nino events in the Upper Wardha watershed of Maharashtra, India. Positive anomaly for the period of La Nina events, results better rainfall while multimodal rainfall observed for El Nino periods in the study region. According to Bothale et al. (2015), El Nino and La Nina impact may vary with respect to the size of the geographical area. The relation among ENSO and yearly climate indices for precipitation were observed prominent. The multimodal nature of precipitation was observed for the El Nino period and heavy rainfall was observed for the La Nina period. The Oceanic Nino Index (ONI) and the precipitation anomalies were prominent during El Nino phase of ENSO. The aim of the present study is to find out the anomalies of yearly extreme climate indices with respect to long term normal years during ENSO events.

\section{Study Area}

Tapi basin is located in the Northern part of the Deccan plateau. The Tapi basin lies between East longitudes of $72^{\circ} 38^{\prime}$ to $78^{\circ} 17^{\prime}$ and North latitudes of $20^{\circ} 5^{\prime}$ to $22^{\circ} 3^{\prime}$. Its area is about $65,145 \mathrm{~km} 2$. The basin is divided into upper, middle and lower sub basins. The Lower Tapi basin is the study area for the present analysis. The annual rainfall of the lower Tapi basins is about 1,042 $\mathrm{mm}$.

\section{Data Collection and Methodology}

Daily rainfall data were collected from state water data centre (SWDC), Gandhinagar for the period 1961 to 2012 for fifteen rain gauge stations.

In the present analysis nine extreme climate indices on the basis of precipitation suggested by the joint World Meteorological Organization(WMO) Commission for the Climatology(CCI)/World Climate Research Programme (WCRP) project on Climate Variability and Predictability(CLIVAR)/Joint WMO- Intergovernmental Oceanographic Commission (IOC) Technical Commission on Oceanography and Marine Meteorology(JCOMM) Expert Team on Climate Change Detection and Indices(ETCCDI) (Peterson et al. 2001; Alexander et al. 2006) have been analysed. The climate indices for precipitation suggested by ETCCDI are as per table 1. These indices have been calculated first and then attempt has been made to find out anomalies with respect to the base period. The Extreme climate indices are classified in three groups viz precipitation frequency based indices (TOTPRCP, RR10 and RR20), precipitation intensity based indices (RX1 day, RX5 day, SDII and R95T) and precipitation duration based indices (CDD and CWD)(Donate et al., 2014). The El Nino and La Nina periods identified based on a threshold of $+/(-) 0.5^{\circ} \mathrm{C}$ for the Oceanic Nino Index(ONI). It is the average of running 3- month SST anomaly for the Nino 3.4 region. This region lies between $0.5^{\circ} \mathrm{N}-0.5^{\circ} \mathrm{S}, 120^{\circ}-170^{\circ} \mathrm{W}$. When five consecutive overlapping 3month SST is at or above the $0.5^{\circ}$ anomaly it is identified as El Nino event. When five consecutive overlapping 3- month SST is at or below the $0.5^{\circ}$ anomaly the event is identified as La Nina. The threshold is further broken down and moderate (1.0 to 1.4), strong (1.5 to 1.9$)$ and very strong $(\geq 2.0)$ SST anomaly events are selected for the present study. Accordingly for the study period 1982, 1986, 1987, 1991, 1997, 2002 and 2009 are the El Nino years while 1988, 1998, 1999, 2007 and 2010 are the La Nina years for the present study region. Anomalies in the yearly extreme indices are found for the year $1981-2010$, which is considered as a base period for the present analysis. 


\section{Analysis and Result}

\subsection{Frequency Based Precipitation Indices}

Anomalies for the yearly extreme climate indices of rainfall for the identified ENSO years have been computed. Anomalies for frequency based indices are as shown in table 2. It is observed from the analysis that almost all the rain gauge stations show positive anomalies for frequency based indices for some years of El Nino events. The negative anomalies have been observed for some years of La Nina events in the present study almost for all the thirteen rain gauge stations. Positive anomalies results an increase in rainfall both in frequency and intensity for the El Nino occasions. Whereas negative anomalies results, decrease in rainfall for the La Nina occasions.

For the El Nino year 1997 positive anomalies have been observed for PRCPTOT for 4 rain gauge stations. While positive anomalies for RR10 have been observed for 6 rain gauge stations and positive anomalies for RR20 have been observed for 5 rain gauge stations. Similarly for the El Nino year 2009 positive anomalies have been observed for PRCPTOT for 7 rain gauge stations, positive anomalies for RR10 have been observed for 6 rain gauge stations and positive anomalies for RR20 have been observed for 11 rain gauge stations. For the La Nina year 1998 negative anomalies have been observed for PRCPTOT for 8 rain gauge stations. Whereas negative anomalies for RR10 have been observed for 4 rain gauge stations and negative anomalies for RR20 have been observed for 6 rain gauge stations. Likewise, for the La Nina year 1999 negative anomalies have been observed for PRCPTOT and RR10 for all the 13 rain gauge stations. While negative anomalies for RR20 has been observed for 12 rain gauge stations. La Nina years 2007 and 2010 also show negative anomalies.

\subsection{Intensity Based Precipitation Indices}

Anomalies for intensity based indices are as shown in table 3. It is observed from the analysis that almost all the rain gauge stations show positive anomalies for intensity based indices for some years of El Nino events. The negative anomalies have been observed for some years of La Nina events in the present study almost for all the thirteen rain gauge stations.

As per Table 3 the El Nino year 2009 shows positive anomalies for Rx1 for 3 rain gauge stations and positive anomalies for Rx5 have been observed for 7 rain gauge stations. Whereas positive anomalies for SDII have been observed for 9 rain gauge stations and positive anomalies for R95T have been observed for 2 rain gauge stations. Similarly for the El Nino year 1982 positive anomalies have been observed for Rx1 for 6 rain gauge stations and positive anomalies for Rx 5 have been observed for 2 rain gauge stations. For the El Nino year 2002 positive anomalies for SDII have been observed for 4 rain gauge stations. The El Nino events 1987, 1997 and 1991 also show positive anomalies for the yearly indices. The La Nina year 1999 show negative anomalies for Rx1 for 11 rain gauge stations and negative anomalies for Rx5 have been observed for 13 rain gauge stations. Whereas negative anomalies for SDII have been observed for 12 rain gauge stations and negative anomalies for R95T have been observed for 12 rain gauge stations. Similarly for the La Nina year 2010 negative anomalies have been observed for Rx1 for 11 rain gauge stations, negative anomalies for Rx5 have been observed for 13 rain gauge stations. While negative anomalies for SDII have been observed for 8 rain gauge stations and negative anomalies for R95T have been observed for 7 rain gauge stations. The La Nina year 1998 show negative anomalies for Rx1 for 6 rain gauge stations and negative anomalies for Rx5 have been observed for 8 rain gauge stations. Whereas negative anomalies for SDII have been observed for 8 rain gauge stations and negative anomalies for R95T have been observed for 6 rain gauge stations. The La Nina year 2007 show negative anomalies for $\mathrm{Rx} 1$ for 8 rain gauge stations and negative anomalies for $\mathrm{Rx} 5$ have been observed for 2 rain gauge stations. While negative anomalies for SDII have been observed for 4 rain gauge stations and negative 
anomalies for R95T have been observed for 7 rain gauge stations. The La Nina year 1988 also shows negative anomalies.

\subsection{Duration Based Precipitation Indices}

Anomalies for precipitation duration based indices are not showing a clear trend of ENSO events. Figure 1, 2 and 3 depict anomalies for the Surat rain gauge station.

\begin{tabular}{|c|c|c|c|c|c|c|c|c|c|}
\hline \multirow{2}{*}{$\begin{array}{l}\text { Rain } \\
\text { gauge } \\
\text { station }\end{array}$} & \multirow[b]{2}{*}{ Year } & \multicolumn{3}{|c|}{ Anomalies (\%) } & \multirow{2}{*}{$\begin{array}{c}\text { Rain } \\
\text { gauge } \\
\text { station }\end{array}$} & \multirow{2}{*}{ Year } & \multicolumn{3}{|c|}{ Anomalies (\%) } \\
\hline & & $\begin{array}{c}P R C P T \\
O T\end{array}$ & $R R 10$ & $R R 20$ & & & $\begin{array}{c}P R C P T \\
O T\end{array}$ & $R R 10$ & $R R 20$ \\
\hline \multirow[t]{3}{*}{ Bodhana } & 1997 & +40.58 & +54 & +46.76 & Songadh & 1991 & - & +12.40 & - \\
\hline & 1998 & -7.13 & - & - & & 2002 & +13.32 & - & - \\
\hline & 1999 & -81.22 & -49.50 & -139.58 & & 1998 & -34 & -1.80 & -30.18 \\
\hline \multirow[t]{2}{*}{ Chalthan } & 2009 & +47.58 & +22.07 & +40.32 & & 1999 & -108.46 & -21.51 & -76.67 \\
\hline & 1999 & -16.13 & -10.90 & -2.78 & & 2007 & -14.46 & -14.14 & -12.42 \\
\hline \multirow[t]{4}{*}{ Kadod } & 2009 & - & - & +18.61 & & 2010 & -15.63 & - & - \\
\hline & 1999 & -61.81 & -23.60 & -22.08 & Surat & 1982 & - & - & +7.59 \\
\hline & 2007 & -13.15 & - & - & & 1997 & - & +5.48 & - \\
\hline & 2010 & -30.43 & - & - & & 2009 & +12.07 & - & +2.16 \\
\hline \multirow[t]{4}{*}{ Kakrapar } & 2009 & - & +3.76 & +20.29 & & 1998 & -10.23 & -5.87 & -18.81 \\
\hline & 1998 & -55.33 & -42.56 & -83.33 & & 1999 & -34.70 & -15 & -27.95 \\
\hline & 1999 & -39.83 & -35.61 & -41 & Ukai & 1997 & +5.53 & - & +4.67 \\
\hline & 2010 & -18.53 & - & - & & 2009 & +10 & +17 & +26.67 \\
\hline \multirow[t]{3}{*}{ Kamrej } & 2009 & +29.97 & +17.96 & +36.44 & & 1999 & -18.67 & -1.72 & - \\
\hline & 1998 & -17.77 & -1.84 & -5.93 & Uteva & 1997 & - & +17.30 & +12.73 \\
\hline & 1999 & -40.81 & -32.24 & -46.67 & & 2009 & - & - & +23.20 \\
\hline \multirow[t]{3}{*}{ Kholvad } & 2009 & +30.48 & +15.05 & +41.28 & & 1998 & -2.68 & - & -28 \\
\hline & 1998 & -3.50 & - & - & & 1999 & -52.59 & -45.71 & -47.69 \\
\hline & 1999 & -49.67 & -46.30 & -69.63 & & 2007 & - & - & -1.05 \\
\hline \multirow[t]{5}{*}{ Mandvi } & 1997 & - & +9.81 & - & Valthan & 1997 & +45.85 & +56.27 & +52.31 \\
\hline & 2009 & - & +12.25 & +11.16 & & 2009 & +5.09 & - & +19.13 \\
\hline & 1999 & -3.99 & -11.95 & -2.17 & & 1998 & -10 & - & - \\
\hline & 2007 & & -1.46 & - & & 1999 & -60.66 & -62.78 & -24 \\
\hline & 2010 & -9.91 & - & - & & & & & \\
\hline \multirow[t]{3}{*}{ Orna } & 1997 & +8 & +23.70 & +9.82 & & & & & \\
\hline & 2009 & +14.58 & - & +22.12 & & & & & \\
\hline & 1999 & $\begin{array}{l}-63.47 \\
\end{array}$ & -83.11 & -114.17 & & & & & \\
\hline
\end{tabular}

${ }^{\text {a. }}$ Note: Numbers with red colour (bold) indicate El Nino events and numbers with blue colour (bold and Italic) indicate La Nina events. Table 2: Anomalies for frequency based precipitation indices

\begin{tabular}{|c|c|c|c|c|c|c|c|c|c|c|c|}
\hline \multirow{2}{*}{$\begin{array}{c}\text { Rain } \\
\text { Gauge } \\
\text { station }\end{array}$} & \multirow[t]{2}{*}{ Year } & \multicolumn{4}{|c|}{ Intensity based indices } & \multirow{2}{*}{$\begin{array}{c}\text { Rain } \\
\text { Gauge } \\
\text { station }\end{array}$} & \multirow[t]{2}{*}{ Year } & \multicolumn{4}{|c|}{ Intensity based indices } \\
\hline & & $\begin{array}{l}\text { Rx1 } \\
\text { day }\end{array}$ & $\begin{array}{l}\text { Rx5d } \\
\text { ay }\end{array}$ & SDII & R95T & & & $\begin{array}{l}\text { Rx1 } \\
\text { day }\end{array}$ & $\begin{array}{l}\text { Rx5d } \\
\text { ay }\end{array}$ & SDII & R95T \\
\hline \multirow[t]{5}{*}{ Bodhana } & 1997 & 13.2 & - & - & - & Songadh & 2002 & 9.7 & 17.3 & 19.8 & 20.4 \\
\hline & 2002 & - & - & 30.0 & - & & 1998 & - & -10.7 & -51.5 & -20.7 \\
\hline & 1998 & - & -6.6 & -12.0 & - & & 1999 & -192 & -85.0 & -65.2 & $\overline{-239.4}$ \\
\hline & 1999 & -20.2 & -15.8 & -78.3 & - & & 2007 & $\begin{array}{ll}-17.1 \\
\end{array}$ & - & -7.5 & -11.8 \\
\hline & 2010 & -68.3 & -43.7 & -10.2 & -7.9 & & 2010 & -97.4 & -64.7 & -17.1 & -77.1 \\
\hline \multirow[t]{4}{*}{ Chalthan } & 2009 & 37.0 & 46.0 & 59.9 & - & Surat & 1982 & 4.3 & - & - & - \\
\hline & 1988 & - & - & 4.5 & - & & 1991 & 5.9 & - & - & - \\
\hline & 1999 & - & -2.8 & -5.3 & -2.8 & & 2009 & 31.8 & 9.0 & 23.2 & 10.8 \\
\hline & 2007 & -50.0 & - & - & -38.7 & & 1998 & - & - & -11.6 & - \\
\hline
\end{tabular}




\begin{tabular}{|c|c|c|c|c|c|c|c|c|c|c|c|}
\hline \multirow{2}{*}{$\begin{array}{c}\text { Rain } \\
\text { Gauge } \\
\text { station }\end{array}$} & \multirow[t]{2}{*}{ Year } & \multicolumn{4}{|c|}{ Intensity based indices } & \multirow{2}{*}{$\begin{array}{c}\text { Rain } \\
\text { Gauge } \\
\text { station }\end{array}$} & \multirow[t]{2}{*}{ Year } & \multicolumn{4}{|c|}{ Intensity based indices } \\
\hline & & $\begin{array}{l}\text { Rx1 } \\
\text { day }\end{array}$ & $\begin{array}{c}\text { Rx5d } \\
\text { ay }\end{array}$ & SDII & R95T & & & $\begin{array}{l}\text { Rx1 } \\
\text { day }\end{array}$ & $\begin{array}{c}\text { Rx5d } \\
\text { ay }\end{array}$ & SDII & R95T \\
\hline & 2010 & -39.8 & $\begin{array}{l}-5.0 \\
\end{array}$ & - & - & & 1999 & - & - & - & -62.5 \\
\hline \multirow[t]{3}{*}{ Kadod } & 1999 & -19.2 & -14.2 & -61.8 & -8.0 & & 2007 & -6.9 & -16.3 & - & -2.2 \\
\hline & 2007 & -8.4 & -17.7 & -13.2 & - & & 2010 & -21.4 & -42.2 & - & -21.2 \\
\hline & 2010 & -80.6 & -44.1 & -30.4 & - & Ukai & 1982 & 39.2 & 7.4 & - & - \\
\hline \multirow[t]{6}{*}{ Kakrapar } & 1982 & 25.4 & - & - & - & & 1987 & 11.8 & - & - & - \\
\hline & 2009 & - & - & 7.3 & - & & 1997 & - & - & - & 13.4 \\
\hline & 1998 & -44.9 & -6.4 & -15.3 & $\begin{array}{ll}-73.6 \\
\end{array}$ & & 2009 & - & 8.3 & 17.8 & - \\
\hline & 1999 & -29.0 & -45.2 & -30.3 & -62.8 & & 1988 & - & -4.1 & - & - \\
\hline & 2007 & -41.6 & - & - & -9.0 & & 1999 & -7.6 & -54.2 & -17.7 & -23.5 \\
\hline & 2010 & -36.7 & -50.1 & -29.2 & -32.1 & & 2010 & -37.1 & -98.0 & - & -11.8 \\
\hline \multirow[t]{4}{*}{ Kamrej } & 2009 & - & 26.2 & 44.7 & - & Uteva & 1986 & 18.0 & 24.8 & 20.7 & - \\
\hline & 1998 & - & -19.0 & -28.5 & -21.4 & & 1997 & - & - & - & 10.6 \\
\hline & 1999 & -6.8 & -21.9 & -58.9 & - & & 2009 & - & - & 19.9 & - \\
\hline & 2010 & - & -9.3 & -15.1 & - & & 1998 & - & - & -3.7 & - \\
\hline \multirow[t]{5}{*}{ Kholvad } & 2002 & - & - & 20.3 & - & & 1999 & -9.6 & -20.6 & -19.9 & -75.7 \\
\hline & 2009 & - & 20.0 & 41.6 & 5.6 & & 2007 & -39.2 & - & -20.9 & -27.0 \\
\hline & 1998 & -6.0 & -15.9 & -25.2 & -12.6 & & 2010 & -33.4 & -44.7 & -37.2 & - \\
\hline & 1999 & -15.3 & -14.8 & -41.2 & -9.3 & Valthan & 1982 & 39.1 & 14.9 & - & 24.2 \\
\hline & 2010 & -6.9 & -7.6 & - & - & & 2009 & - & 11.4 & 32.0 & - \\
\hline \multirow[t]{4}{*}{ Mandvi } & 1982 & 23.7 & - & - & - & & 1998 & -17.4 & -10.1 & -14.1 & - \\
\hline & 1999 & - & -22.0 & - & -9.0 & & 1999 & -20.0 & -15.2 & -15.1 & -93.2 \\
\hline & 2007 & -14.7 & - & - & -11.1 & & 2007 & -42.1 & -18.9 & - & -26.6 \\
\hline & 2010 & -45.9 & -54.7 & - & -61.0 & & & & & & \\
\hline \multirow[t]{6}{*}{ Orna } & 1982 & 12.8 & - & - & - & & & & & & \\
\hline & 2002 & - & - & 11.4 & - & & & & & & \\
\hline & 2009 & 12.8 & 5.8 & 35.2 & - & & & & & & \\
\hline & 1998 & - & -32.9 & -8.8 & -9.0 & & & & & & \\
\hline & 1999 & - & - & -24.0 & -27.0 & & & & & & \\
\hline & 2007 & -111.9 & -56.0 & - & -79.9 & & & & & & \\
\hline
\end{tabular}

${ }^{\text {b. }}$ Note: Numbers with red colour(bold) indicate El Nino events and numbers with blue colour( bold and italic) indicate La Nina events.

Table 3: Anomalies for intensity based precipitation indices

\section{Conclusion}

From the present study, following findings can be summarized:

1. For the base period, El Nino years are 1982, 1986, 1987, 1991, 1997, 2002, 2009 and La Nina years 1988, 1998, 1999, 2007, 2010 are identified.

2. The El Nino years 1997 and 2009 show positive anomalies for precipitation frequency based indices.

3. The La Nina years 1998 and 1999 show negative anomalies for precipitation frequency based indices.

4. The El Nino years 1982, 1987, 1991, 1997, 2002 and 2009 show positive anomalies for precipitation intensity based indices.

5. The La Nina years 1988, 1998, 1999, 2007 and 2010 show negative anomalies for precipitation frequency based indices.

6 . The trend of the duration based precipitation index is not clear for ENSO events. 
7. The positive anomalies of yearly climate indices results into better rainfall in the study region during El Nino events.

8. The negative anomalies of yearly climate indices results in a decrease in rainfall in the study region during La Nina events.

9. It is concluded that ENSO is not directly affecting the rainfall of the study region.

\section{References}

[1] Alexander, L. V., Zhang X., Peterson T. C., Caesar J., Gleason B., Klein Tank A. M. G., Haylock M., Collins D., Trewin B., Rahimzadeh F., Tagipour A., Rupa Kumar K., Revadekar J., Griffiths G., Vincent L., Stephenson D. B., Burn J., Aguilar E., Brunet M., Taylor M., New M., Zhai P., Rusticucci M., Vazquez-Aguirre J. L., "Global observed changes in daily climate extremes of temperature and precipitation,” J. Geophys. Res., vol. 111, pp. D05109, 2006.

[2] Andreoli, R. V., and Kayano, M. T., "ENSO related rainfall anoma-lies in South America and associated circulation features during warm and cold Pacific decadal oscillation regimes," Int. J. Climatol., vol. 25(15), pp. 2017-2030, 2005.

[3] Arblaster, J. M., and Alexander, L. V., "The impact of the El Nino -southern oscillation on maximum temperature extremes," Geophys. Res. Lett., vol. 39, pp. L20702, 2012.

[4] Bothale, R. V., Katpatal, Y. B., "Trends and Anomalies in Extreme Climate Indices and Influence of El Niño and La Niña over Pranhita Catchment in Godavari Basin, India,” J. of Hydrologic Engg, ASCE, vol. 21(2), pp. 05015023, 2015.

[5] Bothale, R. V., Katpatal, Y. B., "Response of Rainfall and Vegetation to ENSO Events during 2001-2011 in Upper Wardha Watershed, Maharashtra, India,” J. of Hydrologic Engg, ASCE, vol. 19(3), pp. 583-592, 2014.

[6] Donat, M. G., et al., "Changes in extreme temperature and precipi-tation in the Arab region: Long-term trends and variability related to ENSO and NAO,” Int. J. Climatol., 34(3), 581-592, 2014.

[7] Peterson, T. C., Folland C., Gruza G., Hogg W., Mokssit A., Plummer N., "Report on the activities of the working group on climate change detection and related rapporteurs 1998-2001." Rep. WCDMP-47, WMO-TD 1071, World Meteorological Organization (WMO), Geneva, vo. 143, March 2001.

[8] International Research Institute for Climate and Society,"ENSO and All - India Rainfall, " Earth Institute, Columbia University. (https://iridl.ldeo.columbia.edu/maproom/ENSO/Climate_Impacts/India_Rainfall.html) (5 Jan. 2017) 


\begin{tabular}{|c|c|c|c|c|c|c|c|c|c|c|}
\hline 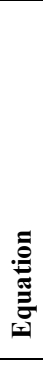 & 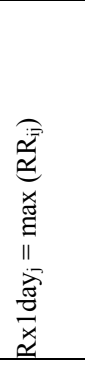 & 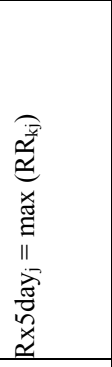 & 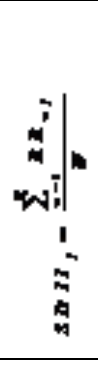 & n & 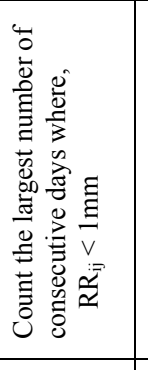 & 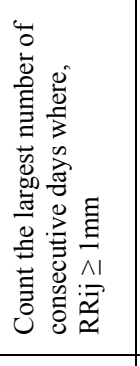 & 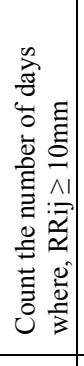 & 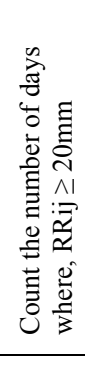 & 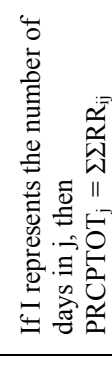 & \\
\hline 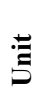 & 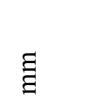 & 声 & $\begin{array}{l}\text { 胥 } \\
\text { 良 }\end{array}$ & 声 & $\overbrace{\overparen{d}}^{\infty}$ & $\overbrace{\overparen{\partial}}^{\infty}$ & $\overbrace{\frac{\mathrm{C}}{\delta}}^{\infty}$ & 突 & 表 & \\
\hline 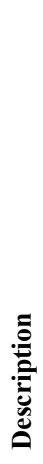 & 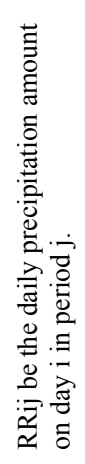 & 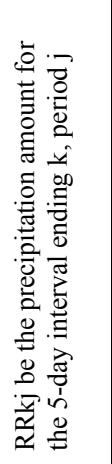 & 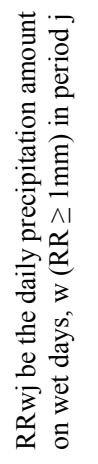 & 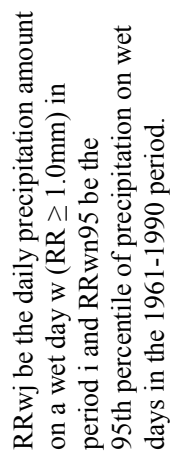 & 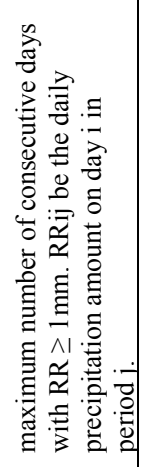 & 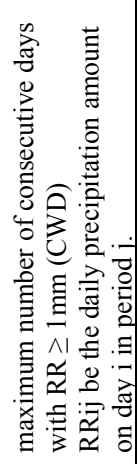 & 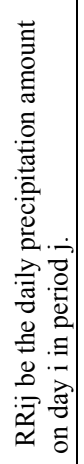 & 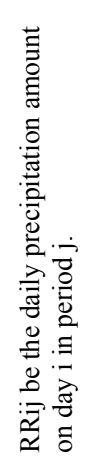 & 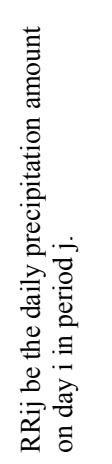 & 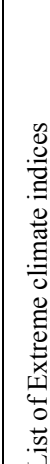 \\
\hline 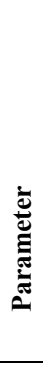 & 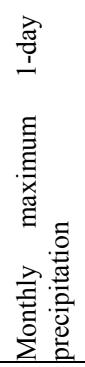 & 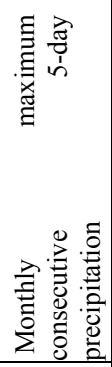 & 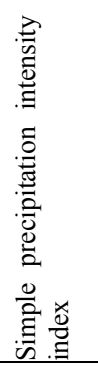 & 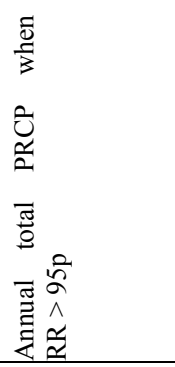 & 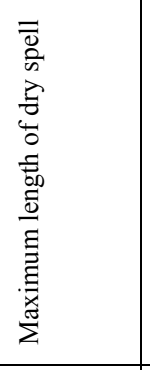 & 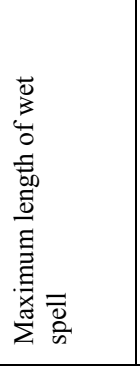 & 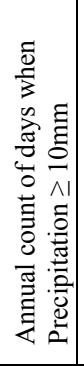 & 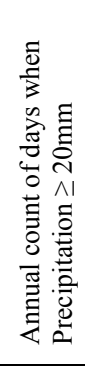 & 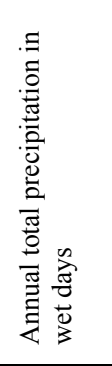 & $\Xi$ \\
\hline 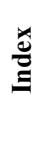 & 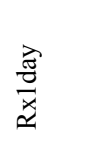 & 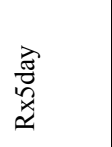 & 藏 & 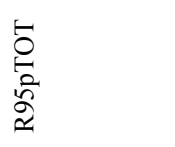 & ठิ & z & $\stackrel{\circ}{\stackrel{\sim}{\simeq}}$ & $\begin{array}{l}\stackrel{\widetilde{\Xi}}{\simeq} \\
\text { }\end{array}$ & 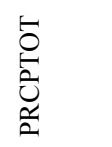 & \\
\hline 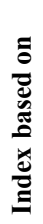 & \multicolumn{4}{|c|}{ 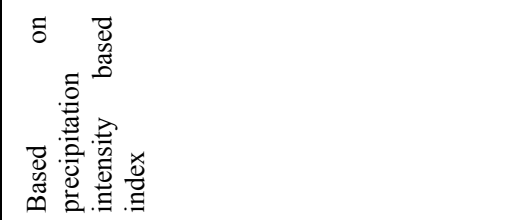 } & \multicolumn{2}{|l|}{ 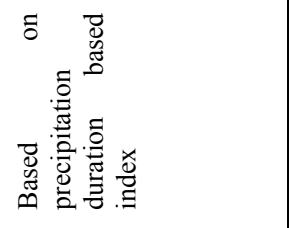 } & \multicolumn{3}{|c|}{ 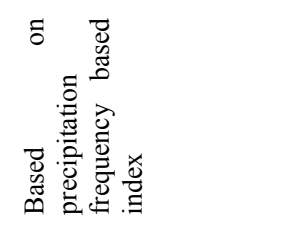 } & \\
\hline
\end{tabular}




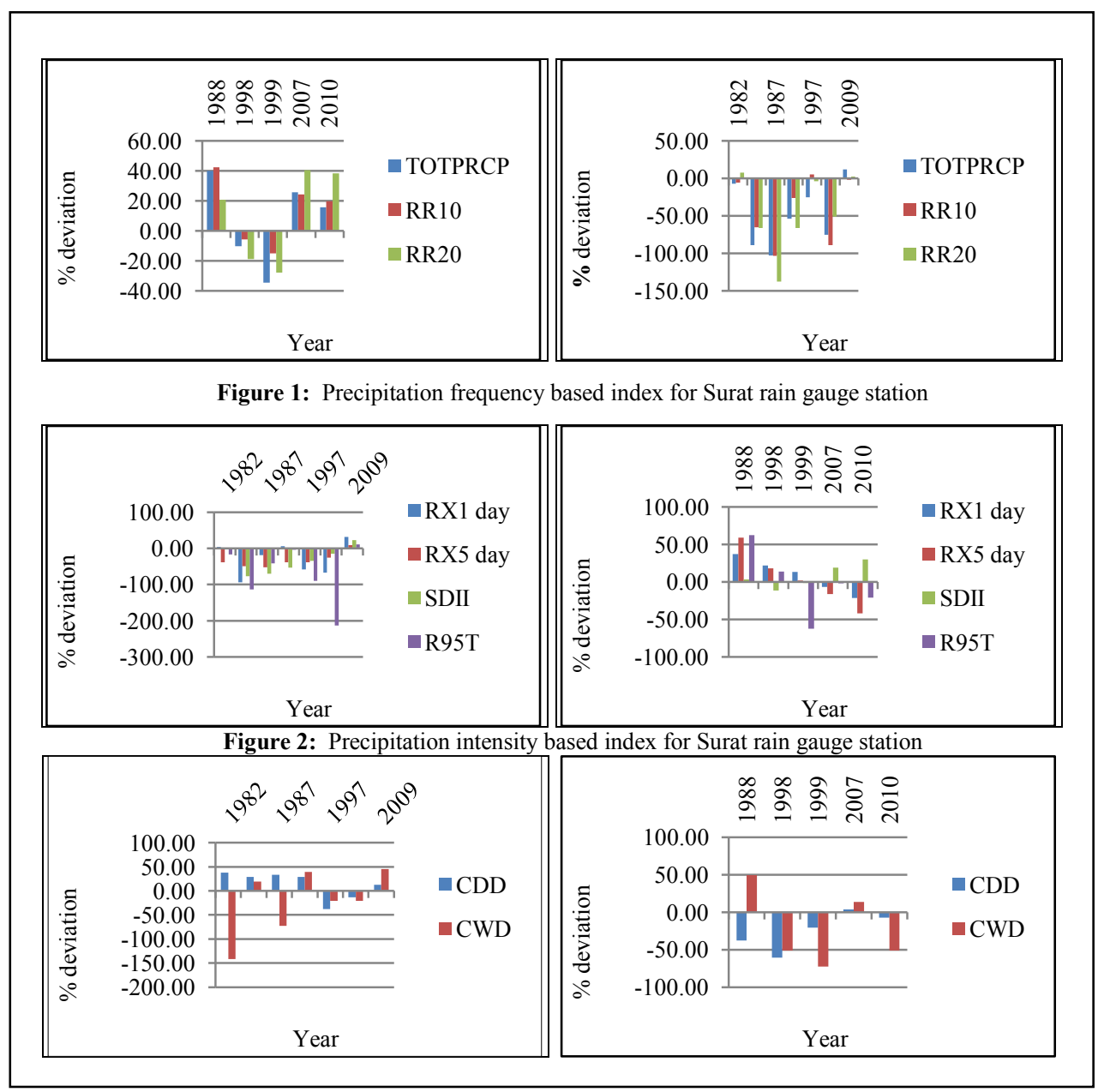

